\title{
Pharmacognostic and Preliminary Phytochemical Analysis of Actiniopteris dichotoma Bedd.
}

\section{Research Article}

\section{Harjeet Singh $^{1^{*}}$, Murali Krishna C ${ }^{1}$, Sanjiv Kumar ${ }^{1}$, Anupam K Mangal ${ }^{2}$}

1. Research officer (Pharmacognosy), 2. Research Officer (Ayurveda), 3. Assistant Director (Ayurveda)

Central Ayurveda Research Institute for Respiratory Disorders (CCRAS), Moti Bagh Road, Patiala (Pb.)

2. Assistant Director, Central Council for Research in Ayurvedic Sciences (CCRAS), Janakpuri, New Delhi

\begin{abstract}
The rhizome and fronds of Actiniopteris dichotoma Bedd. has been reported to treat worm infestations, skin diseases, antifertility, diarrhoea and dysentery in Ayurveda. The present investigation involves the macroscopy, microscopy, physicochemical evaluation and preliminary phytochemical studies of Actiniopteris dichotoma Bedd. These observations will help in carrying out further research on this plant.
\end{abstract}

Keywords: Ayurveda, Pharmacognosy, Actiniopteris dichotom a, microscopy, phytochemical.

\section{Introduction}

Traditional medicines play a key role in human health care. India is a native to a variety of traditional medicinal systems like Ayurveda, Unani and Siddha. Majority of the drugs used in these systems are plant based crude drugs or otherwise finished products in the form of polyherbal formulations. About $80 \%$ of the world population relies on the use of traditional medicine, which is predominantly based on plant material (WHO, 1993). Scientific studies available on medicinal plants indicate that promising phytochemicals can be developed for many health problems. For example, the vinca alkaloids (vincristine, vinblastine and vindesine), derived from Catharanthus roseus, Vinca rosea, Lochnera rosea and Ammocallis rosea have been employed for their anti-cancer properties. Modern pharmaceuticals still contain at least $25 \%$ drugs derived from plants. To preserve the traditional heritage and rationalize the use of natural products in healthcare the safety, efficacy and quality of ASU drugs have to be ascertained. $(1,2)$

The process of evaluating the quality and purity of crude drugs by means of various parameters like morphological, microscopical, physical, chemical and biological observation is called standardization. Standardization is essential for herbal drugs in order to assess the quality of the drugs based on pharmacognostical, phytochemical and biological principles. Traditional remedies have always played an important role in Indian societies. However, among more than 250,000 species of higher plants, only about $10 \%$ have been scientifically investigated. Therefore it becomes necessary to design proper quality control methods for herbal/ASU drugs.(3)

\section{*Corresponding Author:}

\section{Harjeet Singh}

Central Ayurveda Research Institute for Res-

piratory Disorders (CCRAS),

Moti Bagh Road, Patiala (Pb.)

Email id: harjeet_cops@yahoo.com

Phone no: +91 - 9501505323
Pharmacognostic studies help in identification and authentication of the plant material. Appropriate identification and quality assurance of the starting materials is an essential prerequisite to ensure reproducible quality of herbal medicines which will contribute to their safety and efficacy. Simple pharmacognostic techniques used in standardization of plant material include its morphological, anatomical and biochemical characteristics.(4)

Actiniopteris dichotoma (Syn. Actiniopteris radiata; Actiniopteris australis) is a true fern belonging to family Actinopteridaceae. The plant holds a reputed position in Ayurveda but listed among endangered species. It has been used in Ayurveda as an anthelmintic and styptic drug. But these pharmacological activities were contradicted in mice. The sugary paste of the plant is administered to kill the worms in the intestine two times for three consecutive days. The drug is also used as a tonic to increase potency. The plant paste along with candy is administered as a cooling agent in case of syphilis. The whole plant paste mixed with cow's milk is given for the treatment of leucorrhoea and piles. The ash made out of the fresh leaves is taken with honey 2-3 times a day to get relief from bronchitis. Plants are soaked overnight in water and taken orally in the morning for control of blood pressure. The paste prepared from two fronds is given twice a day to children to cure rickets. The paste of 5-6 fronds prepared in the similar way mixed with fresh cow's milk (nearly $200 \mathrm{ml}$ ) is taken for a week, to treat irregular menstrual periods. The powder of 8-10 leaves are mixed with curd is given for birth control. The decoction of leaves is also used in Tuberculosis.

\section{(Mayursikha) Actiniopteris dichotoma Bedd.}

The drug consists of dried rhizome and fronds of Actiniopteris dichotoma Bedd. (Fam. Polypodiaceae). The plant is indigenous, found in dry rocky places throughout India, common in Kumaon Hills and Neelgiris below an altitude of $1200 \mathrm{~m}$ and seen on old buildings.

Though the plant holds a reputed position in Ayurveda but no systematic studies have been 
established. Hence an effort has been made to lay down the Pharmacognostical and phytochemical standards of Actiniopteris dichotoma Bedd.

\begin{tabular}{|c|c|c|c|}
\hline \\
\hline & & \multicolumn{2}{|c|}{ Other/Regional Language Names } \\
\hline English & . & Peacock's tail & \\
\hline Hindi & : & Morpankhi, Mayursiha, & \\
\hline Malayalam & : & $\begin{array}{l}\text { Mauilatumsikha, } \\
\text { Nanmukappullu }\end{array}$ & Mayurasikha, \\
\hline Marathi & : & Mayursikha & \\
\hline Punjabi & : & Morpankhi & \\
\hline Tamil & . & Mayilatum shikhai, May & yircikai \\
\hline Telugu & • & Nemali adugu & \\
\hline
\end{tabular}

\section{Botanical Description}

Actiniopteris dichotoma Bedd. comes under the family Polypodiaceae subfamily Actiniopteridaceae. Similar to other ferns of Pteridophyta, life cycle of the fern also shows alternation of generations of separate sporophyte and gametophyte. Sporophyte generation pre-dominates the gametophyte generation.

A herbaceous miniature palm like plant, height up to $1 \mathrm{~m}$ with densely tufted stipe. Fronds fan-like 2.5$3.8 \mathrm{~cm}$ deep with numerous dichotomous segments which are rush like in texture, veins few, sub parallel with distinct mid rib, segment of fertile frond longer than those of the barren one, sore linear, elongate, sub margin.

\section{Materials and Methods \\ Collection of plant material}

The dried sample of Actiniopteris dichototma Bedd. was procured from NADRI, Bangalore (a unit of CCRAS) and voucher specimens are deposited at Museum of NIAPR, Patiala.

\section{Macroscopic}

The macroscopic characters such as size, shape, margin, nature, texture, apex, surface, colour, odour, taste were studied for morphological investigation.

\section{Microscopic}

For microscopy, free hand section of rhizome of the drug were cut and stained according to the prescribed method. ${ }^{5,6}$ TS shows epidermis as the outermost layer, followed by sclerenchymatous layer, cortex, phloem, xylem and pith in the centre. Dictyostele is present which is dissected type of stele derived from the siphonostele. This is the most advance type of stele (fig 1,2).

\section{Powder microscopy:}

A judicious quantity of powder was taken on a glass slide to which was added a few drops of chloral hydrate and was heated for 1-2 minutes after placing a cover slip, care should be taken to avoid air bubbles and to see that there was sufficient chloral hydrate under the cover slip. Excess of chloral hydrate outside the cover slip is to be withdrawn using a blotting paper.

\section{Physicochemical Evaluation}

The extractive values, ash values and loss on drying were performed according to the official methods prescribed in Ayurvedic Pharmacopoeia of India and WHO guidelines on quality control for medicinal plant materials.(7)

\section{Phytochemical screening}

The preliminary phytochemical screening for stem, leaves and root were carried out as per WHO Guidelines on quality control for medicinal plant materials.(7)

\section{Flourescence Analysis}

Most of the crude drugs fluorescence when their powder is exposed to UV radiation. The fluorescence characteristics of powdered drug were studied under ultraviolet radiation after treating with different chemical reagents. The drugs show characteristic behaviour with different chemical reagents.

\section{Conclusion}

Actiniopteris dichotoma has numerous uses in traditional system of medicine to treat several ailments like worm infestations, skin diseases, antifertility, diarrhoea and dysentery in Ayurveda. Due to its significance in traditional system it becomes necessary to standardize it for use as a drug. No pharmacognostical and phytochemical work on this plant has been reported so far. The present study is undertaken to lay down these standards. The work reveals standardization profile of drug Actiniopteris dichotoma which would be very useful in botanical identification and authentication of plant drug and may help in preventing its adulteration. Present work will be helpful in doing further investigation on the plant.

\section{References}

1. Patwardhan B, Vaidya AD and Chorghade $\mathrm{M}$. Ayurveda and natural product drug discovery. Curr Sci, 2003; 86; 789-799.

2. Mukherjee, P K, Wahile A. Integrated approach towards Drug Development from Ayurveda and other system of medicines, J Ethnopharmacol., 2006; 103:25-35.

3. Anonymous, 1999. The Ayurvedic Pharmacopoeia of India. Part-1, Vol. II Govt. of India, Ministry of Health and Family Welfare, Dept. of AYUSH, New Delhi. pp. 7-9.

4. Anonymous: Macroscopic and microscopic Examination: Quality Control Methods for Medicinal Plant Materials, WHO, Geneva, 1998.

5. Khandelwal, K. R., 2006. Practical Pharmacognosy, Nirali Prakashan, pp. 09-19.

6. Kokate, C. K., 1994. Practical Pharmacognosy, Vallabh Prakashan, pp. 04-29.

7. WHO/PHARM/92.559/rev.1, 1992. Quality Control Methods for Medicinal Plant Materials Geneva: Organization Medicinale De la Sante, Geneva, 9, 22 -34 .

8. Anonymous, 1999. Indian Herbal Pharmacopoeia, IDMA, Vol. II, Mumbai and RRL, Jammu Tawi, pp. 1-8. 
9. Anonymous, The Wealth of India, 1985. Raw Material, Vol.-I, Revised Edition, CSIR, New Delhi, pp. 55-57.
10. Anonymous, The Wealth of India, 2000, Vol. I, First Supplement Series, NISCAIR, New Delhi, pp. 17-18.

Table No 1: Phytochemical constituents in different Extraction mediums

\begin{tabular}{|c|c|c|c|c|}
\hline Phytoconstituents & $\begin{array}{l}\text { Petroleum } \\
\text { Ether extract }\end{array}$ & $\begin{array}{c}\text { Chloroform } \\
\text { extract }\end{array}$ & Methanolic extract & Aqueous extract \\
\hline \multicolumn{5}{|l|}{ Saponins: } \\
\hline Foam test & -ve & -ve & -ve & -ve \\
\hline Haemolytic test & $-\mathrm{ve}$ & -ve & -ve & -ve \\
\hline Shinoda test & -ve & -ve & + ve & + ve \\
\hline \multicolumn{5}{|l|}{ Carbohydrates : } \\
\hline Molish's test & $+\mathrm{ve}$ & $+\mathrm{ve}$ & $+\mathrm{ve}$ & $+\mathrm{ve}$ \\
\hline Fehling's test & -ve & $+\mathrm{ve}$ & $+\mathrm{ve}$ & $+\mathrm{ve}$ \\
\hline Benedict test & $+\mathrm{ve}$ & $+\mathrm{ve}$ & $+\mathrm{ve}$ & $+\mathrm{ve}$ \\
\hline \multicolumn{5}{|l|}{ Phenols and Tannins : } \\
\hline Ferric chloride test & -ve & -ve & $+\mathrm{ve}$ & -ve \\
\hline Gelatin test & & & $+\mathrm{ve}$ & -ve \\
\hline Lead acetate test & + ve & $+\mathrm{ve}$ & $+\mathrm{ve}$ & -ve \\
\hline \multicolumn{5}{|l|}{ Sterols : } \\
\hline Salkowoski's test & $+\mathrm{ve}$ & + ve & $+\mathrm{ve}$ & $+\mathrm{ve}$ \\
\hline $\begin{array}{l}\text { Libermann Buchard } \\
\text { test }\end{array}$ & $+\mathrm{ve}$ & + ve & + ve & $+\mathrm{ve}$ \\
\hline \multicolumn{5}{|l|}{ Alkaloids : } \\
\hline Dragendroff's test & + ve & + ve & $+\mathrm{ve}$ & + ve \\
\hline Hager's test & & & $+\mathrm{ve}$ & $+\mathrm{ve}$ \\
\hline Mayer's test & -ve & -ve & -ve & $-\mathrm{ve}$ \\
\hline Wagner's test & $+\mathrm{ve}$ & + ve & $+\mathrm{ve}$ & + ve \\
\hline \multicolumn{5}{|l|}{ Glycosides : } \\
\hline Borntranger test & -ve & -ve & $+\mathrm{ve}$ & $+\mathrm{ve}$ \\
\hline Legal's test & -ve & -ve & -ve & -ve \\
\hline Keller killani test & $+\mathrm{ve}$ & -ve & $+\mathrm{ve}$ & $+\mathrm{ve}$ \\
\hline \multicolumn{5}{|l|}{ Proteins : } \\
\hline Biuret test & -ve & -ve & -ve & -ve \\
\hline Miller's test & -ve & -ve & -ve & -ve \\
\hline Ninhydrin test & -ve & -ve & -ve & $-\mathrm{ve}$ \\
\hline
\end{tabular}


Table No 2: Powder Analysis with different chemical reagents:

\begin{tabular}{|c|c|c|}
\hline S. No. & Reagent & Colour \\
\hline 1 & Powder as such & Brown \\
\hline 2 & Powder+ conc. $\mathrm{H}_{2} \mathrm{SO}_{4}$ & Brownish black \\
\hline 3 & Powder+ GAA & Dark brown \\
\hline 4 & Powder + conc. $\mathrm{HCl}$ & Brown \\
\hline 5 & Powder + conc. $\mathrm{HNO}_{3}$ & Dark brown \\
\hline 6 & Powder $+5 \% \mathrm{KOH}$ soln & Brown \\
\hline 7 & Powder $+\mathrm{FeCl}$ & Dark brown \\
\hline 8 & Powder $+1 \mathrm{~N} \mathrm{NaOH}$ & Light brown \\
\hline 9 & Powder $+\mathrm{Ammonia}$ & \\
\hline
\end{tabular}

Table No 3: Fluorescence Analysis of Powdered drug of Actiniopteris dichotoma Bedd.

\begin{tabular}{|c|l|l|l|}
\hline S. No. & Reagents & UV (Short) 254nm & UV(long) 366nm \\
\hline 1 & Powder as such & Brown & Brown \\
\hline 2 & Powder $+1 \mathrm{~N} \mathrm{NaOH}$ in water & Fluorescent green & Black \\
\hline 3 & Powder $+50 \% \mathrm{HCl}$ & Light green & Brown \\
\hline 4 & Powder $+50 \% \mathrm{H}_{2} \mathrm{SO}_{4}$ & Fluorescent green & Brown \\
\hline 5 & Powder $+50 \% \mathrm{HNO}_{3}$ & Light green & Brown \\
\hline 6 & Powder + Pet. ether & Light green & Black \\
\hline 7 & Powder $+\mathrm{NH}_{3}$ & Fluorescent green & Dark brown \\
\hline 8 & Powder $+\mathrm{CH}_{3} \mathrm{OH}$ & Light green & Black \\
\hline 9 & Powder $+\mathrm{CHCl}_{3}$ & Green & Black \\
\hline 10 & Powder $+\mathrm{Iodine} \mathrm{Soln}_{3}$ & Green & Black \\
\hline 11 & Powder $+\mathrm{FeCl}_{3}$ Soln & Fluorescent green & Black \\
\hline
\end{tabular}

Table No 4: Physicochemical parameters

\begin{tabular}{|c|l|l|}
\hline S. No. & Parameter & Value(Mean) \\
\hline 1. & Loss on Drying & $4.22 \%$ \\
\hline 2. & Foreign Matter & Nil \\
\hline 3. & Ash value & $5.13 \%$ \\
\hline 4. & Alcohol soluble extractive & $4.02 \%$ \\
\hline 5. & Water soluble extractive & $9.23 \%$ \\
\hline
\end{tabular}




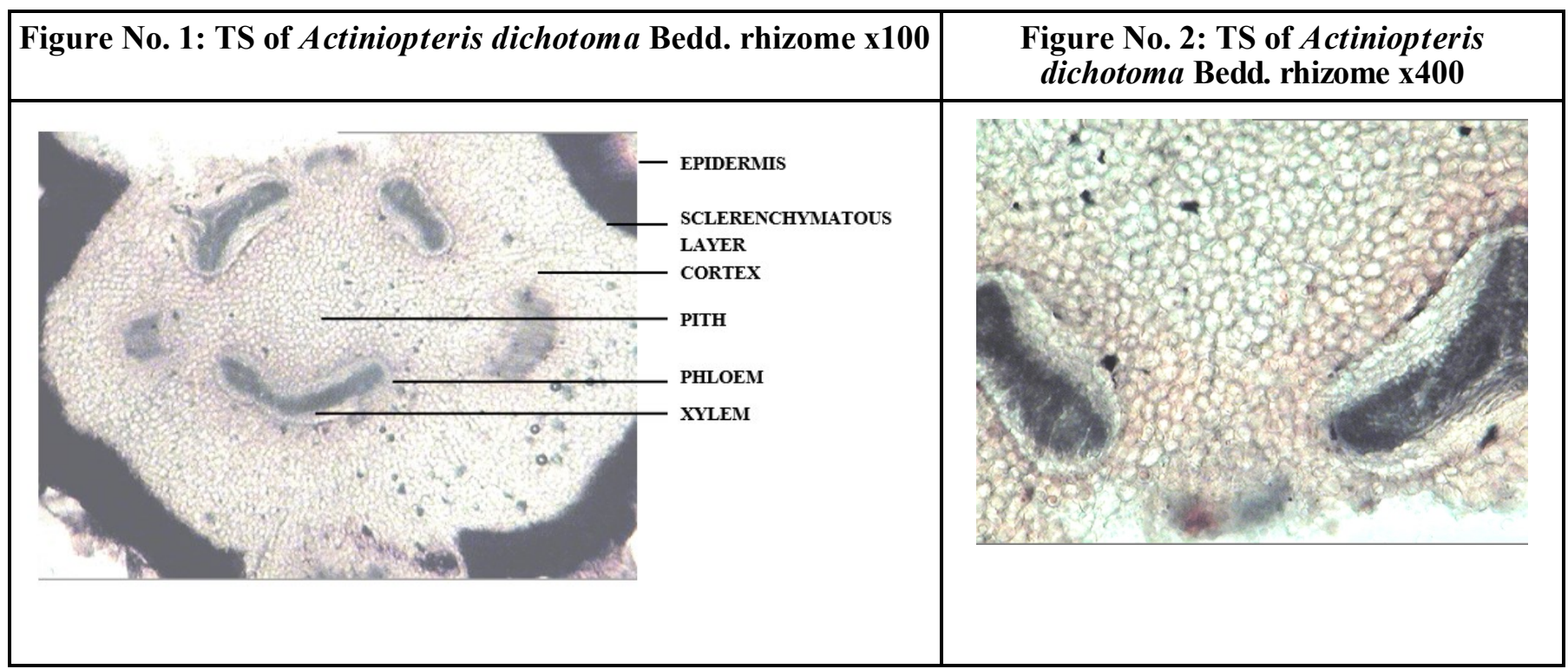

Figure No 3: Powder drug analysis of Actinopteris dichotoma Bedd.
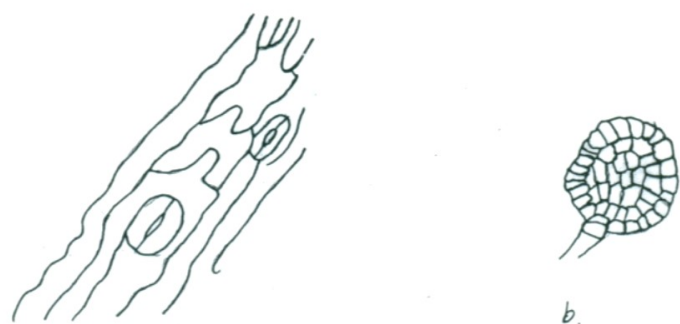

a.

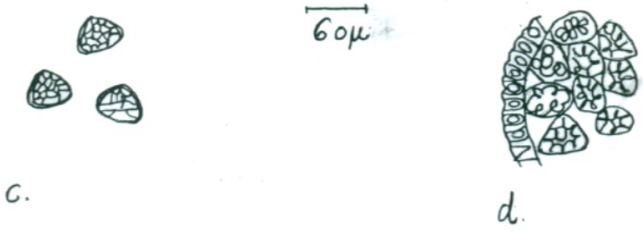

Powder drug analysis of Actiniopteris dichotoma Bedd. (rhizome and fronds), a. Epidermis with stomata, b. Antheridium, c. microspores, d. sporangium 